\title{
Prime Time Nationalism
}

\author{
Patterns of Prejudice in TV Crime Fiction
}

\author{
Wulf Kansteiner
}

\begin{abstract}
Media research has shown time and again that the narrative worlds of prime time television have crafted powerful stereotypes of foreign recalcitrance and criminality. This contribution explores this dynamic through a case study of Germany's most popular prime time television crime fiction series Tatort or Scene of the Crime. Prime time television since the 199os increasingly presented sleek, emotionally manipulative stories of Turkish sexism, Polish slyness, Russian brutality, and Arabic terrorism, helping to establish them as widely shared social memories. It presents a narrative concoction all of its own, representing the liberal collective memory of the failure of multi-culturalism, and conveniently protecting the transnational liberal community from sharing the blame for the failed migration policies of the last decades. This contribution also explores an alternative: we need completely different media strategies to present images of people on the move and now living in our midst. Television prime time fiction and non-fiction should highlight the complexity and multi-causality of the migration experience, thus refraining from essentialising migrant profiles. Moreover, the media should reconstruct the challenges of migration from the moving people's point of view, thus providing powerful vectors of identification for people currently not on the move.
\end{abstract}

Generals always prepare for the most recent war and politicians always manage the most recent migration crisis - or what they and their voters remember as the most recent crisis. In this way collective memories of migration play a decisive role in policy decisions and may prevent societies from developing appropriate responses to resettlement processes.

That was the case in Europe in the year 2016. An estimated 2.2 million people arrived in the territory of the European Union during the so-called refugee crisis in 2015 and 2016 from Syria, Afghanistan, Kosovo, Eritrea and many other countries. ${ }^{1}$ That number represents merely $1.7 \%$ of the 130.9 million people

1 See Conor (2017).

(C) WULF KANSTEINER, 2021 | DOI:10.1163/9789004436107_011

This is an open access chapter distributed under the terms of the CC BY-NC-ND 4.0 license. 
forcefully displaced worldwide in those two years. ${ }^{2}$ Housing, feeding, and educating the two million hardly constitutes a serious financial or material challenge for the EU where, in 2016, 511 million people accumulated a combined GDP of $\$ 16,4$ trillion representing $21 \%$ of the global GDP. ${ }^{3}$ It would take a lot more refugees to overburden the resources of this area of extraordinary wealth. Moreover, in the long run, the refugees and their descendants are likely to become a demographic and financial asset rather than a burden to the EU. ${ }^{4}$ We are clearly not dealing with a material problem but a problem of culture, mentalities, ethics - and memory. Some problems of misperception are shortterm memory problems. The citizens of the EU remember the financial crisis of 2007 accompanied by economic contraction (for the first time since 1945), increased material inequality, and modest decreases in standards of living in some member countries. ${ }^{5}$ That experience might have negatively influenced member societies' willingness to welcome refugees into the EU. Other, more serious memory problems reflect long-term developments. Relevant segments of wealthy Northern European countries entertain decidedly negative views of the enduring consequences of post-WWII immigration events. They remember distinctly the labour migrations from Southern Europe in the 196os and 1970 and from Eastern Europe after 1990 and the influx of political asylum seekers since the 199 os as having harmed their societies. ${ }^{6}$ Again, these negative assessments have little to no basis in fact. For most economists, the migrations in question have had positive rather than negative financial effects on host societies, and crime statistics reveal that only a few specific immigrant groups exhibit a clearly elevated propensity to commit crimes. ${ }^{7}$ It is important to insist on these facts but that hardly suffices. Collective memories are not based in fact; they are based in stories, images, and feelings. Faced with incontrovertible evidence to the contrary, populist politicians across Europe have insisted that they and their voters feel threatened by immigrants. Unfortunately, their feelings are difficult to change. Dealing with dysfunctional memories requires

2 See UnhCr (2016); UnHCR (2017).

See World Bank (2017).

See Kancs, Lecca (2017).

See Magalhaes (2015).

See Wilhelm (2017).

7 For a comprehensive assessment of the economic consequences of post World War II and post Cold War immigration in (West-) Germany see Spencer (1994); Klingst, Venohr (2017). 
effective memory analytics and memory interventions. We need new stories and feelings corresponding to the facts. ${ }^{8}$

The task of developing suitable memories and identities runs up against a veritable paradox. In principle, cultural memories and collective identities are fluid and malleable. Members of different collectives continuously reinvent themselves in symbolic and practical terms by differentiating individuals and groups that fall within their social contracts from those that fall outside of them or attain at best an ambivalent status. Plus, they constantly reshape the very nature of these contracts. For instance, scholars of nationalism have long abandoned the idea that cultural negotiations about the nation and its discontents unfold as stable processes and result in enduring notions of collective identity. They prefer to imagine nations as highly contingent cultural and psychological phenomena involving a wide range of heterogeneous and contradictory communications. ${ }^{9}$ At the same time, imagined communities and their invented traditions, including myths of national belonging, seem to have significant staying power even if they are blurry around the edges. Malleability and persistence are not mutually exclusive characteristics in the politics of memory and identity. The figure of the migrant and stories about migration play a decisive role in Western post-colonial societies' efforts to imagine themselves as sedentary, stable, advanced, civilised, and deservedly affluent. Unfortunately, refugees are subjected to these powerful fantasies of othering that come in many different flavors, from outright xenophobia to arrogant benevolence. ${ }^{10}$

The situation is analytically further complicated by the diversity of media arenas implicated in memory and identity negotiations. Nationally constituted, highly centralised, and transnationally networked old media landscapes like television co-mingle with social media environments with very different, multi-directional patterns of cultural communication and authorship and new forms of concentrated power over communication contents and structures (Hoskins 2018). Yet even if we focus on old media, which are our primary concern in this article, the task of cultural analysis remains complicated. There is

8 On the importance of debate and messaging in counteracting xenophobic political actors, see Lochocki (2018). In this context it is important to consider how European national and transnational government institutions and media companies narrate and remember Europe and the EU. See Spohn, Eder (2016) and especially Bondebjerg et al. (2017). It is also important to avoid the danger of dysfunctional banal Europeanisation; see Trenz (2016).

$9 \quad$ See Brubaker (1996).

10 See Bauman (2016); Nail (2015). 
ample material available to craft a compelling, robust story about the negative impact of TV content on migration memories. Media research, for example, has shown time and again that the narrative worlds of prime time television feature powerful negative stereotypes of foreign recalcitrance and criminality. ${ }^{11}$ As prime time became ever more violent and crime-obsessed in the 199os, hardly an evening went by in the big European TV markets without sleek, emotionally manipulative stories of Turkish sexism, Polish slyness, Russian brutality, and Arabic terrorism, followed by exceedingly repetitive late night talk shows echoing similar views and possibly establishing them as widely shared social memories. ${ }^{12}$ The story can be further elaborated by connecting key elements of popular culture to right wing radicalisation. Effectively enhanced by racist propaganda, compacted collective symbols of alterity may have found an eager audience among the voters of right-wing populist parties who tend to be "male, young(ish), of moderate educational achievement and concerned about immigrants and immigration".13 This stream of repetitive media images and its social base might be the collective memory one is up against in an attempt to build a more inclusive society.

At the same time, the story is hardly that simple. First of all, TV content about foreigners and migration has often not been dominated by negative stereotyping. To name just one example, after $9 / 11$ US commercial television networks featured a great deal of Arab bashing but also a similarly sustained series of programs about good Muslims living the American dream while victimised by US xenophobia. ${ }^{14}$ All of that raises the interesting question of how audiences react to the co-presence of positive and negative stereotyping and, more specifically, of how viewers respond to ironic representations of ethnic and racial prejudice designed to counteract bigotry. ${ }^{15}$ While it makes sense to assume that centralised cultural distribution systems like television offer important information about popular registers of collective identity, one should keep in mind that the carefully designed fantasies of national and ethnic belonging distributed via satellite and cable differ in form and content from the ways in which citizens think and feel about the burden and privileges of group affiliation. After all, even after decades of TV research, we have

\footnotetext{
11 On stereotyping of muslims after 9/11, see Morey, Yaqin (2011); Mertens, de Smaele (2016).

12 See Kretzschmar (2002); Trebbe (2009); Goebel (2017).

13 Arzheimer (2017), p. 287. The storyline is consistent with hegemonic interpretations of right-wing electoral success across Europe, see for instance the analysis of the 2017 federal election in Germany in Spiegel online in Kwasnieski (2017).

14 See Asultany (2012).

15 See Keding, Struppert (2009).
} 
frustratingly little insight into $\mathrm{TV}$ reception processes, although we know for instance that identical media texts may have very different effects in different settings. ${ }^{16}$ Similar questions and lacunae arise when one directs one's analytical gaze at the assumed users of anti-migration memories, for example, the supporters of right wing political parties in Europe. The voter profiles generated by electoral sociologists only reflect the relative affinity between social data and voting decisions and even these profiles might already have been subject to significant mainstreaming. ${ }^{17}$ Moreover and more importantly, relative statements about voting propensities obviously provide no basis for connecting problematic media coverage to specific political phenomenon, for example, by linking the electoral success of the right wing political parties to prejudicial TV programs possibly consumed by their voters. ${ }^{18}$

I apply two conceptual perspectives to analyse the prehistory of the media event refugee crisis. First, a structuralist point of view well suited to highlight the problematic dynamics of post-colonial othering pervasive in Europe's mass media. This traditional approach captures layers and continuities of post-WWII and post-colonial xenophobia and racism, demonstrating that the cultural arena has never been a level playing field for new arrivals. Refugees never had a real chance of inserting themselves successfully into a cultural terrain systematically stacked against them. In addition, I apply a memory studies vantage point that paints a more complicated picture. As the collectively constructed crisis unfolded, two different memory regimes have struggled for supremacy. On the one hand, there were conventionally antagonistically structured memories confirming a simplistic us vs. them divide easily captured by structural analysis. These nationalistic memories contributed to the rise of the radical right across Europe - although it is remarkable how successfully the professed nationalists crafted transnational political and memory networks across the continent. On the other hand, some segments of Europe's societies deployed top-down cosmopolitan memories to frame the crisis within a humanitarian narrative trajectory tapping into human rights and Holocaust memories. Both approaches were successful in that they mobilised political actions, although hardly in any integrated fashion or with comparable degrees of sustainability. The countries following traditional antagonistic storylines far outnumbered the countries willing to give cosmopolitanism a try, as for example Sweden and Germany did. Moreover, in the end, neither memory regime succeeded in providing compelling long-term perspectives and policy

\footnotetext{
16 Lind (2010); Gorton (2009).

17 See Rooduijn (2016).

18 See Arzheimer (2018); Ellinas (2018).
} 
solutions. The antagonistic narrative collides with the simple fact that Europe is a site of irreversible, large-scale migration whereas the cosmopolitan utopia fails to provide practical guidelines for generous yet also clearly circumscribed immigration policies. As we will see, Europe needs a third memory culture that can extend welcome to many more refugees and help with the difficult task of developing ethics of material and legal equality.

With these notes of caution and conceptual contextualisation we now turn to a layer of media history, and arguably also a powerful source of collective memories of migration that predates the 'refugee crisis' by over a decade and thus represents exactly the kind of media fare the witnesses, bystanders, and protagonists of the 'migration crisis' of 2015/16 have consumed over the course of the last decades. Our case study concerns the 2003-2004 season of the German TV series Scene of the Crime (Tatort), which is Germany's Sunday evening prime time flagship program and whose 2003-2004 season featured 34 broadcasts and a number of in-depth engagements with the topic of migration.

\section{Whose Jungle Is It Anyway?}

On October 26th, 2003, 6.5 million German TV viewers watched Berlin detectives Ritter and Stark solve the murder of an illegal immigrant from Nigeria whose corpse had been dumped at the airport. Jungle Brothers (Dschungelbrüder), as the program is provocatively entitled, does not spare any didactic efforts but suffers from a number of shortcomings.

Right at the start, Ritter delivers an impressive yet also improbable impromptu lecture about the pieces of West African jewellery found on the dead man. Further along in the investigation, the Berlin cops dutifully, albeit somewhat laconically, inform the viewers about poverty and corruption in a long list of West African countries, criticize the exploitation of illegal immigrants as a source of cheap labor, and acknowledge that the majority of African immigrants, including people who have lived in Germany for most of their lives, have no chance to attain refugee status. In passing, Ritter and Stark also perfunctorily deplore racism in Germany. But the program does not show vivid instances of racism with the exception of the occasional use of the word darky ('Bimbo') by one of the shadier characters of the story as he addresses his illegal immigrant workers. The program offers theoretical information about xenophobia but does not render it tangible in any meaningful way.

Jungle Brothers has other weaknesses. Perhaps in an attempt at realism in the depiction of police-immigrant relations, the creators of the film have the detectives treat black witnesses and suspects with considerable arrogance and 
distrust. Thus the very carriers of PC-consciousness in the story, whom regular $\mathrm{TV}$ viewers know as compassionate figures, are reinforcing the symbolic divide between Germans and others - notwithstanding the fact that some of the others are German citizens..$^{19}$ Moreover, in order to satisfy the requirements of prime time and in an effort to illustrate that immigrants are human beings just like the viewers in front of the screen, the director has all black actors deliver their lines in flawless German. Thus characters in the story with non-German backgrounds, including recent arrivals, display stunning linguistic capabilities that simply do not reflect everyday life in multi-lingual German cities. ${ }^{20}$ This feat of foreign language acquisition bestows a cyborgian quality on some immigrant figures, inadvertently turning them into a specially marked group of people within the narrative universe on the screen.

However, the most decisive flaw of Jungle Brothers concerns the depiction of the crime itself. In the first scene of the film, the refugee Koffi is murdered by the black father of his girlfriend. The father is a successful business tycoon who immigrated to Germany from Cameroon in the late 1960s. He now owns commercial property all over Berlin and moves in the highest circles of the city, where he is almost but not completely accepted as an equal by his urban jungle brothers. The father finds Koffi unacceptable as a son-in-law, offers him money if he promises to leave his daughter alone, and accidentally kills him in the fight that ensues after Koffi rejects the bribe. Thus, the first-generation black immigrant turns out to be the biggest bigot in the world of Jungle Brothers.

The brief look at the plot structure of Jungle Brothers already hints at a fundamental dilemma that lurks at the intersection of the genre crime show and the topic of migration. The director and screenwriter of Jungle Brothers, Lars Becker, certainly had the best of intentions. He himself is married to a woman of colour and planned to make viewers aware of the problems immigrants face in German society. ${ }^{21}$ But within in the current genre setting, a crime show about migration requires migrants in the roles of victims and/or perpetrators - in addition to a set of more or less heroic non-migrant detectives representing the host society. In this narrative terrain plot options are clearly limited and the creative staff will have to engage with migrant stereotypes in one way or another. That raises tough questions about how much (violent) racism one can responsibly depict on the screen. The problems are exacerbated by Becker's script. How does one turn foreigner-on-foreigner violence into a self-reflexive study of German racism, especially if the viewers learn the identity of the murderer right

\footnotetext{
19 See Wallnöfer (2003).

20 See Bonner Generalanzeiger (2003).

21 See Gehrmann (2003).
} 
after the opening credits? Finally, Becker faced even more of an uphill battle because Jungle Brothers is part of the prestigious series Scene of the Crime that restricted his aesthetic options. The German detective team Ritter and Stark were established prime time figures combining cool with conscience and leaving little space for alternative heroes. Under these circumstances it is not surprising that Becker did not succeed in subverting powerful prejudices. The film follows the conventional rules of the genre and validates the superior sceptical gaze of the enlightened German law-enforcement officers who bring to light the shady dealings and psychological hang-ups of ethnic minorities living in the German capital. Jungle Brothers thus sends a devastating message about German society that probably only partly reflect Becker's political intentions: the integration of black immigrants in Germany is doomed to fail even under the best of circumstances. The immigrants might be economically successful and seemingly well-adjusted but the combination of traditional tribal prejudice, immigrant insecurities, and entrenched German racism may sooner or later turn them into dangerous xenophobes, especially if they successfully emulate German values. ${ }^{22}$ One can easily imagine that these kinds of stories, reproduced in the media on a daily basis, have dire effects. When they intersect with a fear of migration on the part of viewers and the arrival of real migrants, especially migrants perceived as poor and dark-skinned, the stories likely contribute to the collective construction of a 'refugee crisis', especially if the perceived risks and fears of migration are not held in check by countervailing memories.

\section{A Memorial to Whiteness}

As an installment of the series Scene of the Crime (Tatort), Jungle Brothers is part of a venerable German media tradition. Scene of the Crime has been produced for over four decades and, by March 2021, had a record of 1161 original programs, not to mention tens of thousands or reruns. ${ }^{23}$ It might very well be the longest-running prime-time fiction program in the world. Yet while Tatort may rightfully lay claim to global significance in statistical terms and has been broadcast in over 50 countries, it remains a thoroughly German phenomenon that thrives in Germany's peculiar cultural and media landscape. ${ }^{24}$ The 50-year history of Scene of the Crime comprises over seventy-five different investigative

\footnotetext{
22 See Wallnöfer (2003); Bohn (2003a).

23 See Tatort-Fundus (2018a); Brück, Guder, Viehoff, Wehn (2003), pp. 159f.; Hickethier (1998), p. 237; tatort-fans.de (2021).

24 See Hamburger Abendblatt (2016).
} 
teams located in cities all across the Federal Republic. Each team represents a different region with its landmarks and cultural and linguistic peculiarities. Scene of the Crime renders Heimat both regionally specific and nationally recognizable. ${ }^{25}$ In this vein, Scene of the Crime has been a cultural vehicle of national integration in West, East, and unified Germany. Consequently, Scene of the Crime has a large, dedicated, multi-generational cult following that turns the broadcast of new installments into media events. ${ }^{26}$ These audiences expect entertainment and suspense but also social commentary. As a result, Scene of the Crime provides an important platform for political self-reflection with each investigation carefully calibrated to navigate, manipulate, and occasionally challenge the perceived limits of popular taste. In this way, Scene of the Crime presents interesting interpretations of the social and political status quo in Germany. ${ }^{27}$ Every important political issue has been addressed over the years, including East German and West German relations and unification, neo-Nazis and the Nazi past, feminism, social inequality, unemployment, abortion, xenophobia, AIDS, religious sects, euthanasia, prostitution, migration, child labor and abuse, globalisation, and genocide. The people behind Scene of the Crime, including many first-rate directors, screenwriters, and actors, are very aware of the fact that they are managing a national label that offers them extraordinary career opportunities. ${ }^{28}$

There are other developments that have turned Scene of the Crime and similar programs into central sites of cultural memory. Germany's media landscape changed decisively in the early 199os when commercial stations, which had first been licensed in West Germany in 1984, started to match their public service rivals in program diversity and audience appeal. The ensuing competition transformed television fare in Germany, especially during prime time, killing off a number of venerable public service series and formats. ${ }^{29}$ But crime dramas in general and Scene of the Crime in particular have thrived in the new TV environment. Between the mid-1980s and the mid-199os, airtime for primetime cop shows increased more than fivefold. ${ }^{30}$ Scene of the Crime showings jumped from twelve broadcasts in 1989 to over thirty per year since 2002. There

25 See Bollhöfer (2007); Mously (2007).

26 Some Crime Scene investigators have become celebrities - most notably Götz George aka Schimanski - and the introduction of new detectives is vigorously discussed in national tabloids and TV guides; on the Schimanski phenomenon see Harzenetter (1996).

27 See Hißnauer, Scherer, Stockinger (2014).

28 Tatort was for instance the springboard for Wolfgang Petersen's career. He directed a number of episodes in the 1970s, including the famous Reifezeugnis of 1977; see Tatort-Fundus (2018b).

29 See Krüger (2002).

$30 \quad$ Wehn (2002), p. 7f., 194. 
is a simple explanation for this development. Crime dramas constitute one of the few reliable recipes for successful ratings in a crowded field of TV content providers. Scene of the Crime is again a case in point. The series no longer reaches audience shares of over 5 o per cent, which was not unusual during the era of the public service monopoly of ARD and ZDF. But with an average of 8 million viewers and 23 per cent market shares per prime time broadcast, Scene of the Crime has generally remained the most popular program of the primetime line-up on Sunday evening. ${ }^{31}$

At the precise moment when crime shows in general and Scene of the Crime in particular filled ever more airtime, unified Germany experienced increased immigration and a wave of right-wing violence against foreigners in the early 199 os and, partly in response to these events, drastically curbed non-EU immigration by negotiating a system of EU controls. ${ }^{32}$ Yet despite anti-immigration legislation prompted by popular xenophobic resentment, Germany relies on immigrant labor for its economic wellbeing and by 2020 the percentage of foreign citizens and people of so-called non-German background living in Germany had risen to $13,9 \%$ and $26 \%$ respectively. ${ }^{33}$ In this heterogeneous group of approximately 21 million, three million people of Turkish descent represent the largest subsection and, until the events of 2015/16, were considered among the least well-integrated foreigners in Germany. As a result of recent developments, hierarchies of belonging are somewhat in flux in the Federal Republic although there have always been various cultural constructs of migrating Muslims that served as the symbolic antipodes of the constructs 'German' and 'European' in post-Cold War Germany. ${ }^{34}$

German television has played an important role in the remapping of collective national-ethnic identities after the fall of the Berlin Wall. A study from 2007 revealed that 81 percent of the coverage about Muslims on the public stations ARD and ZDF presented Islam in an overwhelmingly negative light. ${ }^{35}$ That figure neatly corresponds to the 83 percent of the German population who held decidedly unfavorable opinions about Islam at that point in time. ${ }^{36}$ Both trends have continued unabated in the last ten years. ${ }^{37}$ However, while these statistics seem to speak a clear language, German television's encounter

\footnotetext{
$31 \quad$ See Tatort-Fundus (2018a).

32 See Geddes, Scholten (2016), p. 95.

33 See Statistisches Bundesamt (2021).

34 See Dietrich, Frindte (2017), p. 112.

35 See Hafez, Richter (2007).

36 See Noelle, Petersen (2006).

37 See Focus-Online (2017); Hafez (2017).
} 
with Islam has been quite complex. TV executives have tried to deal with the problem of racial prejudice by offering viewers a number of critically acclaimed programs calling into question ethnic stereotypes, especially regarding Turks. The programs include the docu-soap Die Özdags (WD R 20078) and the award-winning sitcom Alle lieben Jimmy (RTL 2005-7). ${ }^{38}$ Scene of the Crime itself may serve as another, on first sight positive example. Between 1991 and 2003, partly in response to the wave of xenophobic violence mentioned above, the topic of migration has been addressed, in greater or lesser detail, in almost 20 percent of all Scene of the Crime episodes. ${ }^{39}$ Thus German public television has tried to step up to the plate and media scholars have generally acknowledged these efforts, ${ }^{40}$ although, as we have seen above, engaging with the topic is not synonymous with effectively counteracting xenophobic sentiments. Consider in this context the first (!) German-Turkish detective, Cenk Batu, whom ARD Scene of the Crime executives sent on crime-fighting missions in the gritty urban setting of Hamburg from 2008 to 2012. ${ }^{41}$ Batu retired after only 6 episodes and the figure assumed a very ambivalent profile right from the start. Batu was the only undercover detective in Scene of the Crime. In that role he assumed the personae of Turkish criminals and Islamist terrorists, and, on his last case, went on a vigilante rampage. Consequently, especially on a visual level, Batu often performed rather deconstructed hegemonic cultural patterns of racial prejudice and Muslim migratory threats. ${ }^{42}$ Over half a century, Scene of the Crime has remained a thoroughly racist narrative universe in which white detectives chase white, brown, and black criminals. ${ }^{43}$ Things are only changing slowly. The arrival of a small cohort of Turkish-German investigators represents the most important innovation in this regard. Since 2013 the Hamburg crime team includes the Turkish-German detective Yalcin Gümer who, however, only provides support services to his macho boss Nick Tschiller played by famous, controversial, and equally macho German actor Till Schweiger. Since 2012 and 2017 respectively, the Dortmund and the Kiel team feature young female Turkish-German detectives who embrace (Kiel) or ignore (Dortmund) their non-German heritage. Finally, since 2019,

\footnotetext{
$38 \quad$ See Domaratius (2009).

39 See Ortner (2007), p. 85; Buhl (2014), p. 76.

40 See Wellgraf (2008); Ortner (2007); Thiele (2005).

41 See Tatort-Fundus (2018c).

42 See Spielberger (2012). Similar problems arise with regard to the longest serving immigrant Scene-of-the-Crime detective, Munich's Ivo Batic with Yugoslavian roots, who also suffers from an excess of Mediterranean temper; see Thiele (2005), p. 197.

See the gallery of white and predominantly male detectives at Tatort-Fundus (2018d).
} 
the Ugandan-German actress Florence Kasumba plays the Ugandan-German investigator Anais Schmitz who, in her first appearance on the screen, engages in an activity that breaks with Scene of the Crime etiquette because she physically attacks her female fellow investigator. As of 2021, roughly 10 percent of active investigators are no longer representative of the white, ethnic German mold. That is progress. ${ }^{44}$

Nevertheless, TV networks and critics have simply not paid enough attention to the problematic narrative and aesthetic strategies with which crime shows influence perceptions of foreigners and processes of social integration. Cop shows like Scene of the Crime focus on deviancy and symbolically adjudicate social behavior and in this fashion shape the everyday performance of collective memory. According to Jack Katz, crime shows are so successful and such a great source of historical analysis because they appeal to the audience's strongest-felt positive and negative emotions. By watching crimes unfold on the screen, viewers collectively partake in a daily moral workout that reflects their passionate desire for safety and raises fundamental questions about the reproduction of social order. ${ }^{45}$ Thus popular television offers intriguing interpretations of fundamental fears and hopes, especially with regard to the cultural construction of others. After all, few topics are more emotionally and politically engaging than the question of who does and who does not belong to one's society and how people aspiring to membership should conduct themselves. In this sense, the communications surrounding crime shows about migration touch upon the very essence of human self-consciousness. ${ }^{46}$ Put differently, the serial production of xenophobically structured programs is not just a likely risk in an innovation adverse genre setting like prime time crime, but should actually be recognized as one of the genre's key functions at a time when positive collective self-images in the West appear to be inextricably linked to negative constructions of foreignness and migration. Needless to say, these imagined worlds come with a hefty price tag, first and foremost for migrants, but also for host societies.

\section{3} Orientalising Crime

Lars Becker was not the only creative mind at ARD who used Scene of the Crime in the 2003-4 season to address the topic of migration. In August 2003

\footnotetext{
44 See tatort-fans.de (2020).

45 See Katz (1987).

46 See Rudolph (2007), pp. 49-51.
} 
screenwriter Harald Göckeritz and director Martin Weinhart tackled a particularly thorny issue when they explored the interdependence between illegal migration and the international black market for organ transplants. Their film focuses on the plight of migrants who have been smuggled into Germany under false pretences and are now pressured to serve as organ donors. The refugees have found temporary shelter in a dilapidated public-housing development in Ludwigshafen, where they are eyed with considerable suspicion by the authorities and left unprotected against assaults from an international organ transplant mafia. Detectives Odenthal and Kopper take a close look at the migrants when a refugee headed for the housing development is found dead in a nearby gravel pit. The film quickly focuses on the anguish of a 12-year old Kurdish girl who survived persecution in Turkey and Iraq and now has to fend for herself because her brother, her only remaining relative, has not returned from a mission as an organ donor in Ukraine. ${ }^{47}$

Leyla, broadcast on 31 August 2003 to an audience of 6.9 million viewers, has self-critical potential. Göckeritz and Weinhart forgo any simple happy end. As the detectives are successfully wrapping up their investigation, the camera focuses on another helpless migrant on his way to yet another risky surgery abroad..$^{48}$ In other compelling moments of the film, viewers get a palpable sense of the despair that makes parents of chronically sick children participate in a perfidious system of exchange in which the desperate exploit the poor. Last but not least, the script occasionally assumes the perspective of the refugees, especially by offering a detailed account of the growing panic of 12-yearold Leyla. But the figure of the girl also proves Göckeritz' and Weinhart's downfall. They string together scene after scene of Leyla mournfully inspecting the empty mailbox, placing yet another unanswered call from a public phone booth, or patiently waiting by the window, illuminated by candlelight, with vaguely Middle Eastern music playing in background. The stereotypical spectacle of childlike innocence, flavored with a dash of exoticism, robs the character of complexity and agency, rendering Leyla and her peers defenseless against organ smugglers as well as self-indulgent projections of munificence on the part of the viewers. Leyla is a picture-perfect example of orientalism. ${ }^{49}$

Moreover, the implicit audience constructed in the televisual universe of the film, which is treated to the spectacle of exotic innocence and seemingly invited to identify with Leyla, is defined along narrow ethnic and linguistic

\footnotetext{
$47 \quad$ See Frohn (2003).

48 See Bohn (2003b).

49 A similar process of balkanisation occurs in Scene-of-the-Crime installments dealing with crimes linked to the wars in the former Yugoslavia; see Gladis (2016).
} 
lines that undercut empathetic engagement with the plight of the refugees. The team of investigators and medical support staff, i.e. the heroes of the film, only consists of white, middle-class German native speakers. ${ }^{50}$ This homogenous group of well-adjusted individuals enlightens the audience about a thriving international business of illegal organ transplants in China, Russia, Ukraine, India, Brazil, and the Czech Republic. Through their profile and their actions they draw a line in the sand, somewhere east of Berlin. After all, as Odenthal puts it succinctly on one occasion: "This is Germany." Consequently, all perpetrators are clearly marked as outsiders. The leader of the smuggling enterprise is a stereotypically stoic Russian who kills people without the slightest hesitation; the physician examining the refugees is an ethnic German who grew up in Siberia and still mutters Russian under her breath; the thug who is sent after the victims speaks with the thickest of Bavarian accents, marking him with a powerful sign of alterity according to the cultural codes of the German media.

There are two signs of ambivalence in the neat narrative world of Leyla. The first unpersuasive marker of hybridity is Leyla herself. After only two months in Germany she speaks excellent German. The second character caught between the lines is the social worker Marler, portrayed masterfully by veteran actor and Tatort-regular Jürgen Tarrach. Marler frequently helps the migrants with their everyday problems, but also advises them to accept the deals offered by the smugglers. When confronted by Odenthal and Kopper with the consequences of his corrupt dealings, Marler deeply regrets his actions and contemplates suicide. But he remains the only wrinkle in the tidy national universe of Leyla. ${ }^{51}$ Overall, the film depicts crimes committed by foreigners against foreigners with the former complaining about German laws that complicate their business and about German welfare payments that drive up the prices for organ 'donations'. The viewers can hardly avoid the conclusion that more rules and more aggressive policing are needed in order to force the thugs and their victims to conduct their unappetising business elsewhere - without the benefit of German infrastructure and taxpayer support.

\footnotetext{
50 The picture is complicated by the fact that Tatort aficionados know Kopper to be of Italian-German descent (although that does not play a role in Leyla). In addition, the actress Ulrike Folkerts, who plays Odenthal, is widely known as one of a few openly gay German actresses.

See Bohn (2003b).
} 
In addressing the problems of multiculturalism in Western societies, the makers of Scene of the Crime are clearly handicapped. The crime-drama genre provides only limited opportunities to highlight the positive side of migration. A murder mystery needs a corpse, a murderer, and a compelling motive; a clash of cultures is an excellent plot structure that offers all of the above. In the 2003-2004 season that was clearly the case. Scene of the Crime addressed questions of migration and integration on a routine basis and each time the gripping storylines made a powerful case for cultural homogeneity. In fact, the message could not have been stated more bluntly: the West is better off if it does not get involved in the shady dealings, tribal tensions, and reactionary values of migrant communities. None of the regretful deaths of migrants would have occurred - or at least would not have occurred on Western soil - if the foreigners had simply stayed put. Leyla und Jungle Brothers convey attractive and highly antagonistic memories of migration.

A closer look at the cross-section of crime dramas focusing on migrants and foreigners has revealed rather disappointing results. In each case, the murder is committed by a migrant/foreigner and national identity and mainstream values are affirmed in simplistic ways that offer few opportunities for self-reflection. The programs are obviously not dealing well with the multicultural challenges of the twenty-first century. Under the circumstances it might be helpful to broaden the scope of analysis and gain some comparative perspective. The topic of contemporary migrations seems to overtax the didactic skills and political imagination of the creative staff in charge of crime-drama production. But perhaps screenwriters, directors, and TV executives are more astute in their representation of established and well-integrated minority communities like German Jewry. After all, Western culture has had a lot of opportunities to think about Jewish-Gentile relations and after 1945 these reflections have often taken a decidedly self-critical turn, especially in Germany. Moreover, in particular since the 1970s, television has played a particularly important and often constructive role in Holocaust education. ${ }^{52}$

On December 7 th, 2003, over 7 million viewers watched an aesthetically and politically ambitious episode of Scene of the Crime that painted a critical and discouraging picture of Jewish-Gentile relations in contemporary Germany. The events in The Shochet (Der Schächter) are set into motion by a mentally 
handicapped young man who, in a state of panic, cuts the throat of a homeless boy after having been threatened by the boy's attack dog. The brother of the perpetrator covers up the crime by planting corpse and murder weapon in the house of a shochet, who is subsequently vilified in the press and relentlessly pursued by an antisemitic district attorney. The actual crime and the pursuit of the murderer are not center stage in the program. Instead, the veteran screenwriter Fred Breinersdorfer offers a morality play about persistent antisemitic prejudice in the German provinces. ${ }^{53}$ The convoluted storyline, lacking suspense and veracity but overflowing with didactic ambition, is delivered in carefully constructed, increasingly more disturbing images and combined with an evocative, highly symbolic soundtrack. The program begins with idyllic scenes of the shochet, the lead detective, and the handicapped man playing boule along the banks of Lake Constance. As the case unfolds, the viewers witness the repeated, aggressive interrogation of the shochet staged with Brechtian techniques in sterile early twentieth-century institutional architecture. Apart from the interrogations, the district attorney calmly and seemingly rationally invokes all kinds of antisemitic stereotypes, from greed to blood sacrifice, to bolster his case. Shortly before the climax of the story, director Jobst Oetzmann shifts aesthetic gears and replaces the distance-inducing alienation techniques with subjective camera angles and unsteady camera movements designed to make the viewers sense the rising panic that the shochet, a survivor of Treblinka, experiences as he is once more victimised by German officials. ${ }^{54}$

The director of The Shochet develops a lot of cinematic ambition in an effort to induce empathy with the accused and instill properly anti-antisemitic values in his audience. But the program also contains a number of contradictory plot elements that insert an interesting level of narrative ambivalence and raise doubts about the philosemitic credentials of the lead detective and possibly the program as a whole. ${ }^{55} \mathrm{On}$ the one hand, the proceedings against the shochet are always conducted according to the rule of law, despite the crude antisemitic slogans that the prosecutor delivers outside the courtroom. The lead detective and an impartial judge make sure that justice is done. So the fears of the shochet, especially his growing suspicion of his detective friend, appear increasingly paranoid. On the other hand, a strangely passive lead detective does not seem to resist the antisemitic onslaught as aggressively as one might expect. Moreover and most importantly, viewers are told several times over the course of the film that the shochet spent his childhood in Konstanz, became

53 See Sauerwein (2003).

54 See Heinen (2003).

55 See Gangloff (2003); Anders (2003). 
a well-respected member of the Strasbourg Jewish community after 1945, and only returned to Konstanz on a part-time basis in recent years because he had inherited a beautiful and valuable house on the shore of Lake Constance. Now that he is harassed by law enforcement, the shochet plans his illegal departure from Konstanz and permanent escape to France.

Thus Breinersdorfer invokes antisemitic stereotypes of wandering Jews with shifting loyalties in pursuit of material gain and illustrates how difficult it is to find one's way out of the maze of philo- and antisemitic traditions that are a part of contemporary German culture. In this way, he and Oetzmann open up the film for a wide range of possible readings. Some viewers might have felt encouraged to reflect about their own latent fears of ethnic-cultural alterity and moments of disturbing transference (as Breinersdorfer and Oetzmann probably hoped they would). Others might have come to the conclusion that disengagement seems like the best solution and that the local German-Jewish symbiosis should be ended before worse things happen. In fact, until the very last seconds of the show, the plot and the camerawork squarely point towards segregation and the benefits of ethnic homogeneity. ${ }^{56}$ Finally and most disturbingly, the ambivalences and performances of antisemitism might have prompted some members of the audience to revel quietly in antisemitic prejudice. ${ }^{57}$

Crime shows with Jewish and Holocaust subject matter convey stern warnings about the need for political vigilance and ethnic tolerance, in the case of The Shochet cast into an ambitiously complex and self-reflexive TV story. Everybody involved in television, from producers to consumers, seems to recognize the Holocaust as a site of humility and earnest historical exploration. It is very possible, however, that decades of Holocaust memory work have simply resulted in the creation of narrowly circumscribed cultural ghettoes of cosmopolitan self-reflexivity. The habitual, self-critical impetus noticeable in TV programs with Jewish subject matter does not seem to be transferred to televisual engagements with other contemporary problems of memory whose solutions depend on a similar combination of self-reflexive resolve and innovative zeal. In fact, from a structuralist perspective, the situation appears to be even more sinister. What if the belated, proudly performed critical engagements with the legacy of Nazism play an important role in the thoughtless reproduction of

\footnotetext{
$56 \quad$ See Winter (2015).

57 There are good reasons to assume that a significant share of the audience might have indeed favored this last reading. In December 2003, a month before the broadcast of Der Schächter, a high-profile political scandal broke in Germany that revealed the persistent anti-Semitic sentiments of conservative politicians and their voters. See Herzinger (2003); Kansteiner (2006), pp. 308-12.
} 
contemporary patterns of anti-migration prejudice? Does Holocaust memory facilitate contemporary racism and nationalism? Or have the rituals of German Holocaust culture effectively curbed xenophobia, for instance by helping to create the welcoming culture for refugees that briefly flourished in Germany in 2015-16? Is chancellor Merkel's famous sentence "We'll manage that" ("Wir schaffen das") a concrete application of the ethical demands of Holocaust memory as suggested by the Holocaust survivor Ruth Klüger in her speech to the German parliament in January 2016?58 Maybe 2015 represents a brief, unusual moment in which collective memories of past mass crimes intersected with resettlement processes for the benefit of refugees? Either way, the brief look at the symbolic-ideological dynamics of the media world of primetime crime highlights the difficulties involved in any attempts to brush the genre against the grain and engage in a truly self-reflexive communication with the audience.

\section{$5 \quad$ Levelling the Playing Field}

The culture of prejudice, which is a constituent element of primetime TV, is not representative of all mainstream visual culture. German film and TV culture, for instance, features a long and very successful tradition of anti-xenophobic media stories exemplified by such different media texts as the documentaries of Hans Dieter Grabe from the 1980 s, ${ }^{59}$ or the successful feature films of Fatih Akin produced since $1998 .{ }^{60}$ Even the annals of Scene of the Crime include an exemplary 1998 episode called Trapped (In der Falle), which effectively criticizes the campaign of structural violence waged by the German state against Turkish immigrants. ${ }^{61}$ But, at the same time, the low profile, everyday cultural reproduction of structural racism and nationalism continues unabated. ${ }^{62}$

The above findings offer an opportunity to develop a systematic, structural critique of the crime drama with regard to its construction of alterity. The overwhelming presence and popularity of cop shows give rise to the suspicion that law and order programs have emerged as one of the primary cultural sites

\footnotetext{
$5^{8} \quad$ See Galaktionow (2016).

59 See Hißnauer (2009).

6o See Mackuth (2007); Rings (2016).

61 See Ortner (2007), pp. 139-16o.

62 See for instance the two-part, high-profile 2020 sequel of Tatort entitled "In the family" (In der Familie) marking the 5oth anniversary of the first Tatort broadcast, ARD 29.11.2020 and 06.12.2020. The film presents a picture-perfect xenophobic story featuring an Italian immigrant forced by the Mafia to kill his German wife.
} 
of collective and national identity in a post-Cold-War era in which the media have sworn off the use of overtly nationalistic and xenophobic strategies of representation. In the absence of the kind of clear cut visual and narrative codes circulating at the height of colonialism, fascism, and communism, television producers and their audiences in the West have settled on new master scripts to regain stable Western, European, and national bearings. In this fashion, the crime drama has become a powerful contemporary master symbol whose language, metaphors, and narrative designs are well suited for boosting morale in the respective in-group at the expense of various symbolic others along shifting lines of demarcation. The crime drama has emerged as a site of troublesome historical disinformation and self-fulfilling analytical prophecies. In the course of constantly rewriting and symbolically adjudicating the history of ethnic relations in the West and beyond, popular TV shows provide viewers with powerful tools for the interpretation of contemporary debates about migration, which make them all the more likely to adopt nationalistic and racist points of view. All these factors explain why producing a truly enlightened crime drama about migration seems to require nothing short of subverting the essence of a genre thriving on passive-aggressive politics of exclusion and stereotyping.

In the current cultural context, educational campaigns engaging with the topic of migration face a number of obstacles. The fight against prejudice often seeks to criticize ethnic stereotypes by presenting them in an exaggerated form, the political effects of which are difficult to gauge (Wellgraf 2008, 39). Ironically, the exaggerations are linked to collectively constructed standards of veracity. Viewers expect from television a realistic engagement with contemporary issues, including realistic representations of the kinds of problems they assume exist as a result of migration. But the producers' and viewers' perceptions of reality, which play an important role in successful communication via television, exist largely independent of the type of realism constructed in crime statistics, scholarly papers or other scientific data. In fact, prime time fiction and non-fiction create their own standards of truth. ${ }^{63}$ The exploration of minority communities from the vantage point of law enforcement for instance creates a seemingly compelling causal link between migration and crime and in that respect systematically misrepresents the basic characteristics of actual crimes as well as the efficacy of law enforcement agencies. ${ }^{64}$ Needless to say, the actual conduct of migrants is less important for their perception by host communities than the characteristics attributed to migrants in the media.

\footnotetext{
63 See Enli (2015).

64 See Ortner (2007), p. 176.
} 
In the light of high stakes involved in this media feedback loop, it is useful to recall guidelines for the representation of migrants on $\mathrm{TV}$ developed by the media scholar Christina Ortner. Empathy with members of minority groups is more easily induced by TV stories that feature migrants as main protagonists, present events from the migrants' point of view, and depict the private and professional complexities of their lives. All too often, even in shows designed to criticize xenophobic violence, camera and script linger on the non-migrant perspective in an attempt to understand and condemn anti-migrant sentiments. In addition, the cause of cross-ethnic peace and understanding is more successfully championed by TV programs that emphasize the heterogeneity of in-groups and out-groups and delineate generous criteria for membership in in-groups. ${ }^{65}$

An implementation of these guidelines might indeed result in politically more desirable television programming although the shows would transgress the limits of the genre and no longer meet the expectations of many audience members who take pleasure in watching upstanding white police officers solving the problems of a globalised world. ${ }^{66}$ Ortner's well-intended cosmopolitical guidelines thus inadvertently highlight the structural dilemma inherent in televisual communication and the need for more radical cultural change. Any coverage of a politically sensitive and complex topic like migration, especially in prime time, will nolens volens convey the kind of messages that Roland Barthes has defined as myth, i.e. fairly simplistically structured, easily understood, and semantically over-determined arguments concerning the dangers or advantages of diversity and migration that are difficult to replace by other, ethically, politically, and economically more suitable myths. ${ }^{67}$ Reforming myths about migration amounts to an uphill battle because the cultural terrain in which these negotiations take place does not constitute a level playing field. As Jürgen Link has shown, most collective symbols and metaphors, which have traditionally been used in discussions about difference and migration - and that are thus almost indispensable for effective mass-media communication about the topic - carry a clear bias against many forms of alterity. For instance, the moment any speaker deploys weather, body, house/home, or other territorial metaphors in the context of talk about migrants, the audience is encouraged to wonder about ways to stop the 'flood', close 'leaks' and 'loopholes', or prevent 'invasions' and 'injuries'. In this way foreigners are symbolically burdened with

\footnotetext{
65 See Ortner (2007), pp. 37-46.

66 See Süss (1993), pp. 217, 223.

67 See Barthes (1972), p. 116.
} 
a wide range of negative outcomes, which are not counterbalanced by similarly compelling and extensively used positive symbols. ${ }^{68}$

Obviously, well-meant cosmopolitan memories of migration are a useful point of departure but will not suffice. We need more radically innovative, agonistically structured memories of mobility to bridge the gap between fact and perception and create political options for inclusivity. ${ }^{69}$ How can we better imagine the migration experiences of the past to help solve perceived migration crises today? How can we rethink the population movements of the world wars, the political migrations of the Cold War, and the labour migrations of the age of European affluence to shape the kind of memories that help us foster rather than derail integration processes? How can we lay the foundations for helpful memories of the war in Syria, the destruction of Iraqi society, the misery of continuous warfare in Afghanistan, and the climate migrations of the future in order to help migrants and their reluctant hosts craft a productive, sustainable life together? ${ }^{70}$

\section{Memory Agonistics. Honouring the Refugee and Forgetting the Migrant}

The interpretive feedback loop is all too real: the memory of past mobility, or lack thereof, does amount to a decisive factor in a given society's ability to welcome newcomers as equals. If you conceive of yourself as being part of a tradition of people on the move, it is much easier to relate to people moving towards you. The plasticity of social memories is similarly real. The field of memory studies has proven time and again that what counts in the realm of collective remembrance is not what actually happened but what people feel and think happened. In this fashion, twentieth century culture has moved mountains. Without having had much help in terms of cultural precedents the mass media turned the most brutal and depressing chapters of World War II, Nazi rule, and forced migration into uplifting stories of heroism, innocence, victimhood, and justice accomplished. ${ }^{71}$ In a kind of secular reformation, the survivors of Auschwitz became figures of public veneration in the arena of popular Holocaust memory. ${ }^{72}$ That example illustrates that the plasticity of collective memory

\footnotetext{
68 See Link (1978), pp. 184-222; Link (2006); Link, Jäger (1993); Thiele (2005).

69 See Bull, Hansen (2016).

$70 \quad$ For climate migration see Mayer (2016).

71 See Fogu, Kansteiner, Presner (2016).

72 See Shenker (2015).
} 
defines an important ethical responsibility. As a society we are accountable for our memories and should choose wisely when it comes to remembering the events and stories that define our collective selves. Unfortunately, remembering responsibly is a complicated affair leading invariably to a troublesome paradox. Migration is an excellent case in point. On the one hand, we should do all we can to remember the plight of people who have escaped hardship. They deserve our respect and empathy. A widely shared memory of their suffering and resolve is a precondition for justice and humanitarian action. On the other hand, migrants are not citizens. For instance, the word "migrant" is hardly a neutral term. By designating a person as deserving of special treatment, the word turns that person into a target of discrimination, pity, and arrogance. So we have to forget the migrant and the migrating experience to extend full-term membership in society to new arrivals. To sideline dysfunctional memories, Europe needs to embrace the figure of the refugee as memory icon and forget the migrant's distinctiveness - all at the same time. How do we reconcile these two sound and seemingly diametrically opposed ethical principles?

Societies have different levels of tolerance for moving people and different capabilities of integrating them after their arrival, among other reasons because they develop different memories of migration. In classic immigration societies like the US and Australia, the troublesome and shameful details of mass exodus and deportation from Europe were swiftly pushed aside by uplifting stories of liberty and self-made prosperity at the expense of indigenous populations. Past suffering and dashed hopes were covered up by inauthentic charades of ethnic folklore and fantasies of national unity, which in turn became a solid foundation for democracy and the rule of law. ${ }^{73}$ European societies handled the large population displacements caused by World War II in similar ways. All across Eastern Europe and Germany, refugees, displaced persons, and the many ideologically uprooted sought coverage under fictions of ethnic homogeneity and political consensus. The forces of integration exerted a great deal of structural violence. Languages, heritage, political discontent, and many unwelcome memories disappeared in relentlessly selective invented traditions. The cultural violence designed to hide past enthusiasm for Nazism, extensive collaboration, and a great number of Nazi perpetrators also helped turn refugees into citizens. An impoverished and destroyed continent managed to find homes for at least 15 million migrants, especially in West Germany, and in later years continued that tradition by welcoming millions of people eager to leave Communist Eastern Europe. Ironically, West Germany and many

73 See Bedad (2005). 
of its neighbours meanwhile maintained the fiction that the countries were not immigration societies. ${ }^{74}$ For that purpose they invented new terms for people on the move, including such creative designations as "belated re-settlers" (Spätaussiedler). ${ }^{75}$ The strategies intended to forget the stigma of migration worked wonders for the cause of integration but turned into memory liabilities when migrants from Southern Europe were encouraged to move to the North and did not receive similarly optimistic long-term perspectives and fanciful designations. One is tempted to conclude that the integration of the 15 million succeeded because they were Germans and therefore naturally belonged to Germany, whereas the much smaller group of Southern European arrivals hailed from another culture and could not be integrated as easily. That explanation underestimates the cultural distance between Königsberg and Bavaria and the cultural diversity among the expellees; ${ }^{76}$ the explanation also underestimates the importance of social scripts and social memory for processes of social integration. If the movement of Turks to West Germany in the 196os had been designated as permanent, inevitable, and based on stories of longterm German-Turkish economic collaboration, the descendants of Turkish immigrants would find themselves in a much different position in German society today.

Honouring the refugee and forgetting the migrant does not have to be a contradiction. Cultural memories are never consistent; they are dynamic, multifaceted, and contradictory. Official institutional memories of migration can celebrate the refugee while more fluid everyday media memories help deconstruct the stark artificial divide between migrants and non-migrants. Now that the survivors of the Shoah are leaving the stage, the refugees should take their place. Having overcome war, human trafficking, and persistent prejudice, they deserve their own memorial sites and prominent didactic presence in schools, museums, and the media. Permanently inscribed in our cultural memories, the figure of the refugee could make sure that we remember their woes and accomplishments and strive to live up to the dictum of "never again!" So we are advocating here for a mobility turn in memory studies and the politics of memory, conceptualising moving people not as deficient vis-à-vis an allegedly static location from which they emerge (emigration) or to which they aspire (immigration). Instead, the process of movement itself becomes the focus of analytical and narrative interest resulting in a wide spectrum of multi-directional memories reflecting a range of nomadic experiences and diasporic feelings that

\footnotetext{
74 See Wilhelm (2017).

75 See Menzel, Engel (2014).

76 See Rock, Wolff (2002).
} 
include such different perspectives as that of the exchange student and civil war refugee without obliterating the dissimilarities between them. ${ }^{77}$ Social and media scripts that acknowledge differences of opinion and interests regarding the movement of people while de-essentialising these differences could lay the foundation for agonistic memories of migration and agonistic debates about the privileges of affluent birth and the limits of human solidarity. What difference should this perspective make for prime time crime? A lot and very little. Television is hardly at the cutting edge of twentyfirst century's media technologies. Future memories of flight and migration will be negotiated in immersive gaming and AI environments. ${ }^{78}$ But let's pretend for a moment that we could rewrite media history. In Leyla and Jungle Brothers script and camera could for instance have stayed with the moving victims and moving perpetrators, rendering their decisions and behaviour complex, intriguing, and plausible. The detectives should have been much more diverse and sported a moving background easy to relate to. Itinerancy, deviancy and helplessness, on the one hand, and settledness, integrity and power, on the other hand, should not have formed such a rigid semantic contrast. If more fluid stories of people movements had been widely spread in primetime crime at the beginning of the new millennium, perhaps the welcoming culture of 2015/16 might have lasted just a little bit longer.

The scripts for better stories of movement can be found in the real world. Between 2013 and 2017 , over $24 \%$ of newly hired police officers in Berlin hailed from a minority background, but the Scene-of the-Crime detectives serving in Berlin, who were hired in 2015, still exude settled whiteness. ${ }^{79}$ The toughest challenge in building new collective memories of movement remains the deconstruction of racism. ${ }^{80}$

\section{Bibliography}

Alsultany, Evelyn (2012). Arabs and Muslims in the Media. Race and Representation after 9/11 (New York: New York University Press).

Anders, Manfred (2003). 'Film verwechselt', Sächsische Zeitung 12 September.

Arzheimer, Kai (2017). 'Electoral Sociology. Who Votes for the Extreme Right and Why and When', in Cas Muddle (ed.), The Populist Radical Right (London: Routledge), pp. $277^{-289}$.

77 See Nail (2015); Sheller, Urry (2006).

78 See de Smale et al. (2017).

79 See Mediendienst-Integration (2017); Tatort-Fundus (2018e).

$80 \quad$ See Kansteiner (2019). 
Arzheimer, Kai (2018). 'Explaining Electoral Support for the Radical Right', in Jens Rydgren (ed.), The Oxford Handbook of the Radical Right (Oxford: Oxford University Press), pp. 143-165.

Bauman, Zygmunt (2106). Strangers at Our Door (Cambridge: Polity).

Barthes, Roland (1972). Mythologies (London: Cape).

Bedad, Ali (2005). A Forgetful Nation. On Immigration and Cultural Identity in the United States (Durham, NC: Duke University Press).

Bohn, Angelika (2003a). 'Spannender Wettlauf', Ostthüringer Zeitung, 28 October.

Bohn, Angelika (2003b). 'Das Organ-Geschäft. Nur ein Teilerfolg erzielt der Tatort Leyla', Ostthüringer Zeitung, 9 February.

Bollhöfer, Bjørn (2007). Geographien des Fernsehens. Der Kölner 'Tatort' als mediale Verortung kultureller Praktiken (Bielefeld: transcript).

Bondebjerg, Ib et al. (eds) (2017). Transnational European Television Drama. Production, Genre and Audiences (Cham: Palgrave Macmillan).

Bonner Generalanzeiger (2003). 'Tödliche Langeweile', 28 October.

Brubaker, Rogers (1996). Nationalism Reframed. Nationhood and the National Question in the New Europe (Cambridge: Cambridge University Press).

Brück, Ingrid, Andrea Guder, Reinhold Viehoff, Karin Wehn (2003). Der deutsche Fernsehkrimi. Eine Programm- und Produktionsgeschichte von den Anfängen bis heute (Stuttgart: Metzler).

Buhl, Hendrik (2014). 'Zwischen Fakten und Fiktionen', in Christian Hißnauer, Stefan Scherer, Claudia Stockinger (eds), Zwischen Serie und Werk. Fernseh- und Gesellschaftsgeschichte im "Tatort" (Bielefeld: transcript), pp. 67-87.

Bull, Anna, Hans Hansen (2016). 'On Agonistic Memory', Memory Studies, 9.4, pp. 390-404.

Connor, Phillip (2017). 'Still in Limbo. About a Million Asylum Seekers Await Word on Whether They Can Call Europe Home', Pew Research Center Global Attitudes \& Trends, 20 September. http://www.pewglobal.org/2017/og/20/a-million-asylumseekers-await-word-on-whether-they-can-call-europe-home/ [accessed 10.08.2017].

De Smale, Stephanie et al. (2017). 'The Case of This War of Mine. A Production Studies Perspective on Moral Game Design', Games and Culture, 8.29, pp. 1-6.

Dietrich, Nico, Wolfgang Frindte (2017). 'Einstellungen zu Muslimen und zum Islam II und der Terrorismus', in Nico Dietrich, Wolfgang Frindte (eds), Muslime, Flüchtlinge und Pegida. Sozialpsychologische und kommunikationswissenschaftliche Studien in Zeiten globaler Bedrohungen (Wiesbaden: Springer), pp. 89-137.

Domaratius, Jana (2009). 'Cultural Diversity Mainstreaming in Türkisch für Anfänger und Alle lieben Jimmy', in Claudia Böttcher, Judith Kretschmar, Markus Schubert (eds), Heimat und Fremde. Selbst-, Fremd- und Leitbilder in Film und Fernsehen (Munich: Peter Lang), pp. 199-214.

Ellinas, Antonis (2018). 'Media and the Radical Right', in Jens Rydgren (ed.), The Oxford Handbook of the Radical Right. (Oxford: Oxford University Press), pp. 269-284. 
Enli, Gunn (2015). Mediated Authenticity. How the Media Constructs Reality (New York: Peter Lang).

Focus-Online (2017). '70 Procent der Deutschen finden, dass der Islam nicht zu Deutschland gehört', 4 October. https://www.focus.de/politik/videos/repraesentat tive-umfrage-70-prozent-der-deutschen-finden-dass-der-islam-nicht-zu-deutschland-gehoert_id_6o27429.html [accessed 21.01.2018].

Fogu, Claudio, Wulf Kansteiner, Todd Presner (eds) (2016). Probing the Ethics of Holocaust Culture (Cambridge, Mass.: Havard University Press).

Frohn, Axel (2003). 'Ulrike Folkerts. Die dienstälteste TV-Kommissarin feiert heute Jubiläum im Tatort Leyla', Berliner Zeitung, 31 August.

Galaktionow, Barbara (2016). 'Holocaust-Überlebende nennt "Wir schaffen das" einen heroischen Slogan', Süddeutsche Zeitung, 27 January.

Gangloff, Tilmann (2003). 'Irgendwann rächt sich alles', Stuttgarter Zeitung, 12 June.

Geddes, Andrew, Peter Scholten (2016). The Politics of Migration and Immigration in Europe. 2nd edn (Los Angeles: Sage).

Gehrmann, Alva (2003). 'Plastikleichen pflastern seinen Weg', Der Tagesspiegel, 15 June.

Gladis, Lea (2016). 'Mapping Stereotypes und Tatort. Aspekte stereotyper Perzeptionen Südosteuropas im 21. Jahrhundert', in Nina Frieß et. al. (eds), Grenzräume - Grenzbewegungen (Potsdam: Universitätsverlag), pp. 49-62.

Goebel, Simon (2017). Politische Talkshows über Flucht. Wirklichkeitskonstruktionen und Diskurse. Eine kritische Analyse (Bielefeld: transcript).

Gorton, Kristyn (2009). Media Audiences. Television, Meaning and Emotion (Edinburgh: Edinburgh University Press).

Hafez, Kai (2017). 'Der Islam in den Medien. Der Islam hat eine schlechte Presse', Zeit Online, 21 February. http://www.zeit.de/gesellschaft/zeitgeschehen/2016-12/ islam-verstaendnis-medien-berichterstattung-populismus-gefahr [accessed 21.01.2018].

Hafez, Kai, Carola Richter (2007). 'Das Islambild von ARD und ZDF', Aus Politik und Zeitgeschichte 26-27, pp. 40-46.

Hamburger Abendblatt (2016). 'Der Tatort wird in rund 50 Ländern ausgestrahlt', 12 November.

https://www.abendblatt.de/wirtschaft/article208704647/Der-Tatort-wird-in-rund-50Laendern-ausgestrahlt.html [accessed 15.01.2018].

Harzenetter, Wilma (1996). Der Held 'Schimanski' in den 'Tatort'-Folgen des WDR. Ein Protagonist der achtziger Jahre (Alfeld: Coppi).

Herzinger, Richard (2003). 'Der Fall Hohmann. Raunen, Angst und Haß', Die Zeit, 13 November.

Heinen, Christina (2003). 'Blut und Boule. Tatort über Antisemitismus', Frankfurter Rundschau, 12 June.

Hickethier, Knut (1998). Geschichte des Deutschen Fernsehens (Stuttgart: Metzler). 
Hißnauer, Christian (2009). 'Fremdes Deutschland. Heimat und Fremde aus der Sicht von Migranten. Hans-Dieter Grabes Dokumentarfilme der 1980er Jahre', in Claudia Böttcher et. al. (eds), Heimat und Fremde. Selbst-, Fremd und Leitbilder in Film und Fernsehen. (Munich: Martin Meidenbauer Verlagsbuchhandlung), pp. 35-46.

Hißnauer, Christian, Stefan Scherer, Claudia Stockinger (eds) (2014). Zwischen Serie und Werk. Fernseh- und Gesellschaftsgeschichte im 'Tatort' (Bielefeld: transcript).

Hoskins, Andrew (ed.) (2018). Digital Memory Studies. Media Pasts in Transition (New York: Routledge).

Kancs, d'Artis, Patrizio Lecca (2017). Long-term Social, Economic and Fiscal Effects of Immigration into the EU. The Role of the Integration Policy. JRC Working Papers in Economics and Finance 4, doi:10.2760/999095.

Kansteiner, Wulf (2006). In Pursuit of German Memory. History, Television, and Politics after Auschwitz (Athens, OH: Ohio University Press).

Kansteiner, Wulf (2011). 'What is the Opposite of Genocide? Philosemitic Television in Germany, 1963-1995', in Jonathan Karp, Adam Sutcliffe (eds), Philosemitism in History (Cambridge: Cambridge University Press), pp. 289-313.

Kansteiner, Wulf (2019). 'Migration, Racism and Memory,' Memory Studies, 12.6, pp. 611-616.

Katz, Jack (1987). 'What Makes Crime 'News?', Media, Culture, and Society, 9, pp. 47-75.

Keding, Karin, Annika Struppert (2009). Ethno-Comedy im deutschen Fernsehen (Leipzig: Frank \& Timme).

Klingst, Martin, Sascha Venohr (2017). 'Wie kriminell sind Flüchtlinge? Was die Kriminalstatistiken der Bundesländer über die Zunahme von Gewalttaten seit 2015 verraten. Sechs Trendmeldungen zur Zuwanderungskriminalität', Zeit Online, 19 April. http://www.zeit.de/2017/17/kriminalitaet-fluechtlinge-zunahme-gewalttatenstatistik [accessed 10.09.2017].

Kretzschmar, Sonja (2002). Fremde Kulturen im europäischen Fernsehen. Zur Thematik der fremden Kulturen in den Fernsehprogrammen von Deutschland, Frankreich und Großbritannien (Wiesbaden: Westdeutscher Verlag).

Krüger, Udo (2002). Programmprofile im dualen Fernsehsystem 1991-2000 (BadenBaden: Nomos).

Kwasnieski, Nicolai (2017). 'Wie Gehalt, Beruf und Wohnort die Wahlentscheidung prägen', Spiegel Online, 19 July. http://www.spiegel.de/wirtschaft/soziales/bundestagswahl-2017wer-waehlt-cdu-csu-spd-fdp-gruene-linke-afd-a-1158543.html [accessed 30.01.2018].

Lind, Rebecca Ann (2010). Race/Gender/Media. Considering Diversity Across Audiences, Content, and Producers. 2nd edn (Boston: Pearson).

Link, Jürgen (1978). Die Struktur des Symbols in der Sprache des Journalismus. Zum Verhältnis literarischer und pragmatischer Symbole, (Munich: Fink).

Link, Jürgen (2006). Versuch über den Normalismus. Wie Normalität produziert wird. 3rd edn (Göttingen: Vandenhoeck \& Ruprecht). 
Link, Jürgen, Siegfried Jäger (eds) (1993). Die vierte Gewalt. Rassismus und die Medien. (Duisburg: Duisburger Institut für Sprach- und Sozialforschung).

Lochocki, Timo (2018). The Rise of Populism in Western Europe. A Media Analysis of Failed Political Messaging (Cham: Springer).

Magalhaes, Pedro (ed.) (2015). Financial Crisis, Austerity, and Electoral Politics. European Voter Responses to the Global Economic Collapse 2009-2013 (New York: Routledge).

Mackuth, Margret (2007). Es geht um Freiheit. Interkulturelle Motive in den Spielfilmen Fatih Akins (Saarbrücken: Akademikerverlag).

Mayer, Benoît (2016). The Concept of Climate Migration. Advocacy and Its Prospects (Cheltenham: Elgar).

Mediendienst-Integration (2017). 'Beamte mit Migrationshintergrund. Wie entwickelt sich die Vielfalt bei der Polizei?', ı. https://mediendienst-integration.de/fileadmin/ Dateien/Polizisten_mit_Migrationshintergrund_2017.pdf [accessed 05.02.2018].

Menzel, Birgit, Christine Engel (eds) (2014). Rückkehr in die Fremde. Ethnische Remigration russlanddeutscher Spätaussiedler (Berlin: Frank \& Timme).

Mertens, Stefan, Hedwig de Smaele (eds) (2016). Representations of Islam in the News. A Cross-Cultural Analysis (Lanham, MD: Lexington Books).

Moray, Peter, Amina Yaqin (2011). Framing Muslims. Stereotyping and Representation after 9/11 (Cambridge MA: Harvard University Press).

Mously, Sara (2007). Heimat im Fernsehen. Eine medienpsychologische Untersuchung am Beispiel des "Tatort”. (Saarbrücken: VDM).

Nail, Thomas (2015). The Figure of the Migrant (Stanford: Stanford University Press).

Noelle, Elisabeth, Thomas Petersen (2006). 'Allensbach-Analyse. Eine fremde, bedrohliche Welt', Frankfurter Allgemeine Zeitung, 17 May.

Ortner, Christina (2007). Migranten im Tatort. Das Thema Einwanderung im beliebtesten deutschen TV-Krimi (Marburg: Tectum).

Rings, Guido (2016). The Other in Contemporary Migrant Cinema. Imagining a New Europe? (New York: Routledge).

Rock, David, Stefan Wolff (eds) (2002). Coming Home to Germany? The Integration of Ethnic Germans from Central and Eastern Europe in the Federal Republic since 1945 (New York: Berghahn).

Rooduijn, Matthijs (2016). 'Closing the Gap? A Comparison of Voters for Radical Rightwing Populist Parties and Mainstream Parties', in Tjitske Ackermann et al. (eds), Radical Right-Wing Populist Parties in Western Europe. Into the Mainstream? (New York: Routledge), pp. 53-69.

Rudolph, Ulrich (2007). Die Visualität der Teilsysteme. Intersubjektivität der Wahrnehmung visueller Symbole am Beispiel einer Tatort-Filmreihe (Marburg: tectum).

Sauerwein, Uwe (2003). 'Tatort-Krimi gegen Antisemitismus. Der Schächter dreht sich um die uralte Legende vom Ritualmord', Berliner Morgenpost, 7 December. 
Shandler. Jeffrey (1999). While America Watches. Televising the Holocaust (New York: Oxford University Press).

Sheller, Mimi, John Urry (2006). ‘The New Mobilities Paradigm', Environment and Planning, 38, pp. 207-226.

Shenker, Noah (2015). Reframing Holocaust Testimony (Bloomington, IN: Indiana University Press).

Spencer, Sarah (ed.) (1994). Immigration as an Economic Asset. The German Experience (London: Trentham).

Spielberger, Christoph (2012). 'Befehl des NDR. Cenk Batu muss erschossen werden', achgut.com, 7 May. [accessed 31.01.2017].

Spohn, Willfried, Klaus Eder (eds) (2005). Collective Memory and European Identity. The Effects of Integration and Enlargement (London, New York: Routledge).

Süss, Daniel (1993). Der Fernsehkrimi, sein Autor und die jugendlichen Zuschauer (Bern: Huber).

Statistisches Bundesamt (2021). 'Migration und Integration,' 29 March. https://www. destatis.de/DE/Themen/Gesellschaft-Umwelt/Bevoelkerung/Migration-Integration/_inhalt.html (accessed 02.04.2021).

tatort-fans.de (2021). https:// tatort-fans.de (accessed 02.04.2021).

Tatort-Fundus (2018a). 'Folgen' http://www.tatort-fundus.de/web/folgen.html [accessed 15.02.2018].

Tatort-Fundus(2018b).'Reifezeugnis'.http://www.tatort-fundus.de/web/folgen/chrono/ 1/1977/o73-reifezeugnis.html [accessed o8.07.2010].

Tatort-Fundus (2018c). 'Batu'. http://www.tatort-fundus.de/web/ermittler/sender/ndr/ batu.html [accessed 31.01.2018].

Tatort-Fundus (2018d). 'Ermittler'. http://www.tatort-fundus.de/web/ermittler/ alphabetisch-sortiert.html [accessed 02.02.2018].

Tatort-Fundus (2018e). 'Nina Rubin und Robert Karow'. http://www.tatort-fundus. de/web/ermittler/sender/rbb-rundfunk-berlin-brandenburg/karow-rubin.html [accessed 02.02.2018].

Thiele, Matthias (2005). Flucht, Asyl und Einwanderung im Fernsehen (Konstanz: UvK Verlagsgesellschaft).

Trebbe, Joachim (2009). Ethnische Minderheiten, Massenmedien und Integration (Wiesbaden: VS Verlag).

Trenz, Hans-Jörg (2016). Narrating European Society. Towards a Sociology of European Integration (Lanham, MD: Lexington Books).

UNHCR, The UN Refugee Agency (ed.) (2016). Global Trends. Forced Displacements 2015 (Geneva: UNHCR).

UNHCR, The UN Refugee Agency (ed.) (2017). Global Trends. Forced Displacements 2016 (Geneva: UNHCR).

Wallnöfer, Pierre (2003). 'Lügen wie gedruckt', Salzburger Nachrichten 28 October. 
Wehn, Karin (2002). 'Crime-Time' im Wandel. Produktion, Vermittlung und Genreentwicklung des west- und ostdeutschen Fernsehkrimis im Dualen Rundfunksystem (Bonn: ARCult-Media).

Wellgraf, Stefan (2008). Migration und Medien. Wie Fernsehen, Radio und Print auf die Anderen blicken (Berlin: Lit).

Wilhelm, Cornelia (ed.) (2017). Migration, Memory, and Diversity. Germany from 1945 to the Present (New York: Berghahn).

Winter, Renee (2015). 'Tatort', in Wofgang Benz (ed.), Handbuch des Antisemitismus. Judenfeindschaft in Geschichte und Gegenwart, Bd.7. Literatur, Film, Theater und Kunst (New York, Berlin: de Gruyter), pp. 484-486.

WorldBank(2017).'DataEuropeanUnion'.https://data.worldbank.org/region/europeanunion [accessed 08.10.2017]. 